\title{
EFEKTIVITAS PUPUK ORGANIK CAIR FPUKT-1 TERHADAP HASIL CABAI BESAR VARIETAS DARMAIS F1
}

\author{
(Effectiveness Of FPUKT-1 Liquid Organic Fertilizer On The Results Large Chili \\ Of Darmais F1 Variety)
}

\author{
Sundari $^{1}$, Candra Catur Nugroho ${ }^{1}$, dan Halimah Tusaddiah ${ }^{2}$ \\ ${ }^{1}$ Program Studi Agroteknologi, Faperta Universitas Kutai Kartanegara \\ ${ }^{2}$ Alumni Program Studi Agroteknologi, Faperta Universitas Kutai Kartanegara \\ Penulis koresponden: candracatur@unikarta.ac.id
}

Article Submitted: 05-11-2020

Article Accepted: 21-12-2020

\begin{abstract}
This research aimed to determine the effect of FPUKT-1 liquid organic fertilizer (LOF) on the yield of large chili plants var. Darmais F1. This research was arranged by Randomized Block Design (RBD) with an analysis of factorial FPUKT-1 consisted of eight levels and repeated three times, i.e $p_{0}$ (control), $p_{1}\left(20 \mathrm{ml} \mathrm{L}^{-1}\right.$ water $), \mathrm{p}_{2}\left(40 \mathrm{ml} \mathrm{L}^{-1}\right.$ water $), \mathrm{p}_{3}\left(60 \mathrm{ml} \mathrm{L}^{-1}\right.$ water), $\mathrm{p}_{4}\left(80 \mathrm{ml} \mathrm{L}^{-1}\right.$ water $), \mathrm{p}_{5}\left(100 \mathrm{ml} \mathrm{L}^{-1}\right.$ water $), \mathrm{p}_{6}\left(120 \mathrm{ml} \mathrm{L}^{-1}\right.$ water $), \mathrm{p}_{7}\left(140 \mathrm{ml} \mathrm{L}^{-1}\right.$ water). The results showed that the FPUKT-1 LOF had a significant effect on the average age of flowering plants and the number of cropping fruit, also had no significant effect on the average yield of fruit crop and the fresh fruit per hectare. The result of the highest per hectare fruit obtained at a rate of $\mathrm{p}_{6}\left(120 \mathrm{ml} \mathrm{L} \mathrm{L}^{-1}\right.$ water $)$ with an average of $4.45 \mathrm{t} \mathrm{ha}^{-1}$, while the lowest gained at the $\mathrm{p}_{0}$ level (control) with an average $2.18 \mathrm{t} \mathrm{ha}^{-1}$.
\end{abstract}

Keywords: Chili, Fertilizer, Organic

\section{PENDAHULUAN}

Cabai besar (Capsicum annum L.) merupakan cabai yang memiliki nilai ekonomis yang cukup tinggi. Buahnya dapat digolongkan sebagai sayur maupun bumbu dapur, tergantung bagaimana cabai digunakan. Kebutuhan cabai meningkat setiap tahun karena jumlah penduduk yang bertambah banyak sehingga berkembangnya industri yang membutuhkan bahan baku cabai. Cabai menjadi salah satu komoditas sayuran yang banyak dibutuhkan masyarakat saat ini, baik masyarakat lokal maupun internasional. Permintaan cabai semakin bertambah setiap harinya seiring meningkatnya jumlah penduduk di berbagai negara.

Badan Pusat Statistika Provinsi Kalimantan Timur (2020), melaporkan hasil produksi cabai besar di Kalimantan Timur pada tahun 2016 yaitu $3.367,3$ ton dengan luas panen 704 ha, sedangkan pada tahun 2017 hasil produksi meningkat yaitu $3.503,1$ ton dengan luas panen 727 ha dan pada tahun 2018 hasil produksi semakin meningkat yaitu 4.166,7 ton dengan luas panen 814 ha. Dinas Pertanian dan Peternakan Kabupaten Kutai Kartanegara (2019), melaporkan bahwa hasil produksi cabai besar di Kabupaten Kutai Kartanegara pada tahun 2016 sebesar 1.687 ton dengan luas panen 254 ha, sedangkan pada tahun 2017 produksi meningkat menjadi 1.882 ton dengan luas panen 281 ha dan pada tahun 2018 produksi sedikit menurun menjadi 1.696 ton dengan luas panen 279 ha.

Budidaya cabai memiliki prospek usaha yang masih sangat menjanjikan, bukan hanya untuk pasar domestik saja namun juga berpeluang untuk memenuhi pasar ekspor, 
walaupun terkadang harga cabai mengalami ketidak stabilan usaha cabai sangat penting karena cabai merupakan salah satu kebutuhan yang selalu digunakan di setiap masakan. Salah satu alternatif untuk meningkatkan hasil produksi tanaman cabai besar yaitu dengan menggunakan pupuk organik. Pupuk organik merupakan pupuk yang sebagian besar terdiri atas bahan organik yang berasal dari tanaman atau hewan yang telah melalui proses rekayasa. Pupuk organik dibedakan menjadi dua berdasarkan bentuknya yaitu pupuk organik cair dan pupuk organik padat (Susetya, 2015).

Pupuk organik yang menjadi nutrien bagi tanaman menggunakan bahan dasar yang diambil dari alam. Pada penelitian ini digunakan pupuk organik cair (POC) FPUKT I yang berbahan dasar tanaman kacang panjang, kangkung, gula pasir, pisang sanggar, teratai, air kelapa. Pada pupuk organik cair FPUKT I ini terdapat $\mathrm{C}$ organik $0,85 \%, \mathrm{~N}$ total $0,05 \%$, $/ \mathrm{N}$ rasio $17, \mathrm{P}_{2} \mathrm{O}_{5} 0,013 \% \mathrm{mg} / \mathrm{l}, \mathrm{K}_{2} \mathrm{O} \quad 0,017 \%$ $\mathrm{mg} / \mathrm{l}$ diduga dapat meningkatkan perkembangan cabai besar, membuat tanaman lebih hijau, mempercepat tumbuhnya bunga dan buah (Laboratorium Tanah Fakultas Pertanian Universitas Mulawarman, 2019).

Berdasarkan informasi diatas, sehingga perlu dilakukan penelitian terkait efektivitas POC FPUKT-1 terhadap hasil tanaman cabai besar (Capsicum annum L.). Penelitian ini bertujuan untuk mengetahui pengaruh POC FPUKT-1 terhadap hasil tanaman cabai besar (Capsicum annum L.) varietas Darmais F1.

\section{METODOLOGI PENELITIAN}

\section{Waktu dan Tempat}

Penelitian ini dilaksanakan pada bulan Januari 2020 sampai bulan Mei 2020. Lokasi penelitian bertempat di Kelurahan Bukit Biru, Kecamatan Tenggarong, Kabupaten Kutai Kartanegara Provinsi Kalimantan Timur.

\section{Bahan dan Alat}

Bahan yang digunakan dalam penelitian adalah benih cabai besar varietas Darmais F1, teratai, gula, pisang sanggar, kacang panjang, air kelapa, kangkung, jerami, tanah, dolomit, pupuk kandang ayam, NPK mutiara, SP-36. Sedangkan alat-alat yang digunakan terdiri dari meteran, potray, tangki air, gembor, waring, parang, mesin pemotong rumput, rotary, handtractor, cangkul, penggaru, plywood, ajir, paku, palu, spidol, ajir, bak air, jerigen 20 liter, plastik, karung, dan timbangan.

\section{Rancangan Penelitian}

Rancangan penelitian yang digunakan adalah Rancangan Acak Kelompok (RAK), dengan perlakuan POC FPUKT-1 (P) terdiri dari 8 taraf dan diulang sebanyak 3 kali yaitu $\mathrm{p}_{0}=$ kontrol, $\mathrm{p}_{1}=20 \mathrm{ml} \mathrm{L}^{-1}$ air, $\mathrm{p}_{2}=40 \mathrm{ml}$ $\mathrm{L}^{-1}$ air, $\mathrm{p}_{3}=60 \mathrm{ml} \mathrm{L}^{-1}$ air, $\mathrm{p}_{4}=80 \mathrm{ml} \mathrm{L}^{-1}$ air, $\mathrm{p}_{5}$ $=100 \mathrm{ml} \mathrm{L}^{-1}$ air, $\mathrm{p}_{6}=120 \mathrm{ml} \mathrm{L}^{-1}$ air, dan $\mathrm{p}_{7}=$ $140 \mathrm{ml} \mathrm{L}^{-1}$ air.

\section{Pelaksanaan Penelitian}

\section{Persiapan lahan}

Pada lahan yang digunakan sebagai tempat penelitian, terlebih dahulu dibersihkan dari gulma dan kotoran lainnya. Pengolahan tanah dengan cara dibajak menggunakan handtractor agar menjadi gembur kemudian dicangkul untuk meratakan dan membuat petakan. Lahan yang telah selesai diolah dibuat 3 kelompok sebagai ulangan. Setiap kelompok dibagi menjadi 8 petak dengan ukuran $2 \mathrm{~m} \mathrm{x}$ 2,80 $\mathrm{m}$, jarak antar ulangan $1 \mathrm{~m}$ dan jarak antara petak dalam ulangan $50 \mathrm{~cm}$.

\section{Penyemaian}

Untuk menanam benih di potray pada media semai adalah campuran tanah dan jerami 1:1 lalu dimasukkan ke potray. Benih yang disemai direndam terlebih dahulu ke dalam air hangat selama 15 menit. Jumlah benih yang disemai \pm 500 benih.

3. Pembuatan pupuk

Pupuk organik cair FPUKT-1 dibuat pada saat tanaman cabai berumur 26 hari setelah semai. Proses pembuatan pupuk organik cair FPUKT-1 yaitu: 1) kacang panjang $(8 \mathrm{~kg})$, pisang kapok $(20 \mathrm{~kg})$, teratai (20 kg), dan kangkung ( $8 \mathrm{~kg}$ ) dipotong kecilkecil $3 \mathrm{~cm}$, lalu dimasukkan ke dalam wadah yang besar; 2) gula pasir ( $5 \mathrm{~kg}$ ), dan air kelapa 
(20 liter) dimasukkan ke dalam wadah; 3) kemudian semua bahan tersebut diaduk hingga tercampur rata; 4) setelah itu, wadah dibungkus menggunakan plastik hingga rapat; 5) lalu didiamkan selama 7 hari.

4. Pemupukan

Untuk menetralkan $\mathrm{pH}$ tanah maka diberikan dolomit pada saat pengolahan tanah dengan dosis $2,24 \mathrm{~kg}_{\text {petak }}{ }^{-1}$. Pupuk kandang ayam diberikan pada saat 4 hari setelah pengolahan tanah dengan dosis $11 \mathrm{~kg}$ petak $^{-1}$ diberikan dengan cara disebar. SP-36 diberikan pada saat 8 hari setelah pengolahan tanah dengan dosis $140 \mathrm{~g}^{\text {getak }}{ }^{-1}$ dengan cara disebar. NPK mutiara diberikan pada saat 7 hari setelah tanam dengan dosis $210 \mathrm{~g}$ petak $^{-1}$. Pengaplikasian pupuk organik cair FPUKT I diberikan setiap 10 hari sekali setelah tanam sesuai konsentrasi pada perlakuan masingmasing tanaman cabai.

\section{Penanaman}

Penanaman dilakukan pada bibit cabai yang sudah berumur 4 minggu dan bibit terlihat baik secara fisik. Penanaman dengan cara bibit dimasukkan ke dalam lubang yang sudah ditugal terlebih dahulu dengan kedalaman $\pm 6 \mathrm{~cm}$, dengan jarak tanam $50 \mathrm{~cm} x$ $70 \mathrm{~cm}$, tiap petak ditanam sebanyak 16 tanaman cabai. Penanam dilakukan pada pagi hari. Pengelompokan berdasarkan tinggi tanaman cabai, (kelompok I : $10 \mathrm{~cm}$ ), (kelompok II : $12 \mathrm{~cm}$ ), (kelompok III : $14 \mathrm{~cm}$ ).

6. Pemasangan ajir

Pemasangan ajir dilakukan pada saat tanaman cabai berumur 14 hari setelah tanam.

7. Pemeliharaan

Kegiatan yang dilakukan pada saat pemeliharaan diantaranya penyiraman, penyulaman, penyiangan dan pembumbunan, perampelan, dan pengendalian hama dan penyakit:

a. Penyiraman

Penyiraman pada tanaman diberikan sebanyak $200 \mathrm{ml}$ tanaman $^{-1}$ dari awal tanam hingga tanaman berumur 4 minggu, $300 \mathrm{ml} \mathrm{tanaman}^{-1}$ dari tanaman berumur 4 minggu hingga berumur 8 minggu, dan 400 $\mathrm{ml}$ tanaman $^{-1}$ dari tanaman berumur 8 minggu hingga panen. Penyiraman dilakukan 2 kali dalam setiap hari dengan menyesuaikan kondisi tanah. Penyiraman menggunakan gembor yang sudah ditakar untuk satu tanaman.

b. Penyulaman

Penyulaman dilakukan pada tanaman yang rusak atau mati. Pada penelitian ini tidak dilakukan penyulaman karena tidak ada tanaman cabai yang rusak atau mati.

c. Penyiangan

Penyiangan dilakukan dengan cara membersihkan atau mencabut gulma yang ada pada lahan budidaya, penyiangan dilakukan saat tanaman berumur 7 hari setelah tanam dan penyiangan selanjutnya dilakukan 7 hari sekali.

d. Pembumbunan

Pembumbunan dilakukan saat tanaman cabai berumur 14 hari setelah tanam.

e. Perempelan

Perempelan dilakukan dengan memotong tunas samping yang tumbuh di ketiak daun ataupun cabang tanaman yang tidak produktif dan perempelan dilakukan 7 kali sejak tanaman pada saat tanaman berumur 21 hari setelah tanam sampai panen.

f. Pengendalian Hama dan Penyakit

Pengendalian hama dan penyakit yaitu menggunakan pestisida anorganik. Pada peneltian ini hama yang dominan menyerang ialah lalat buah, gejala kerusakan yang terlihat oleh lalat buah yaitu adanya lubang pada buah cabai yang masih muda, sedangkan akibat dari bakteri Erwinia carotovora yaitu pangkal ujung buah bewarna coklat kehitaman. Cara pengendalian yaitu dengan menggunakan insektisida merk Curacron 500 EC berbahan aktif Profenofos 500 g/l dengan dosis $1 \mathrm{ml} \mathrm{L}^{-1}$ air penyemprotan dilakukan 1 kali pada umur 56 hari.

8. Panen

Pemanenan pertama dilakukan saat tanaman berumur 62 hari setelah tanam atau ketika buah sudah bewarna hijau mengkilap, selanjutnya pemanenan dilakukan selang 
waktu 7 hari sekali. Pemanenan dihentikan saat produksi sudah mengalami penurunan.

\section{Parameter Pengamatan}

Pengambilan data dilakukan dengan cara acak sistematis pada tanaman sampel yang berjumlah 4 tanaman. Beberapa parameter pengamatan diantaranya sebagai berikut :

1. Umur tanaman berbunga (hari)

Umur tanaman saat berbunga dihitung pada saat muncul bakal tunas bunga sejak tanam. Untuk tanaman berbunga dihitung minimal $80 \%$ tanaman berbunga dari keseluruhan populasi pada satu petak.

2. Jumlah buah pertanaman (buah)

Jumlah buah pertanaman dihitung pada saat setiap panen dibagi tanaman sampel yang

$$
\text { Hasil t ha } \mathrm{t}^{-1}=\frac{\text { luas per hektar }\left(\mathrm{m}^{2}\right)}{\text { luas petak hasil }\left(\mathrm{m}^{2}\right)} \times \frac{\text { hasil per petak }(\mathrm{kg})}{1000 \mathrm{~kg}} \times 1 \mathrm{tha}^{-1}
$$

\section{Analisis Data}

Data yang terkumpul kemudian dianalisis dengan uji $\mathrm{F}$ taraf 5\% Jika hasil uji $\mathrm{F}$ menunjukan adanya pengaruh nyata atau sangat nyata, maka dilanjutkan dengan Uji Beda Nyata Jujur (BNJ) taraf 5\%.

\section{HASIL DAN PEMBAHASAN}

Hasil analisis menunjukkan bahwa perlakuan pemberian pupuk organik cair (POC) FPUKT-1 berpengaruh sangat nyata terhadap rata-rata umur tanaman berbunga (Gambar 1) dan berpengaruh nyata terhadap rata-rata jumlah buah pertanaman. Umur tanaman berbunga tercepat dihasilkan dari berjumlah 4 lalu hasil panen pertama hingga terakhir dijumlahkan.

3. Hasil buah segar pertanaman (g)

Hasil buah segar pertanaman dihitung pada saat setiap panen dibagi tanaman sampel yang berjumlah 4 lalu hasil panen pertama hingga terakhir dijumlahkan.

4. Hasil buah segar perhektar $\left(\mathrm{t} \mathrm{ha}^{-1}\right)$

Hasil buah segar dihitung dengan cara menjumlahkan semua buah hasil panen pertama hingga panen terakhir pada setiap petak. Penghitungan dilakukan pada seluruh tanaman yang ada dalam petak hasil yang berjumlah 16. Kemudian dikonversikan ke dalam satuan $\mathrm{t} \mathrm{ha}^{-1}$ dengan rumus:

perlakuan $\mathrm{p}_{3}\left(60 \mathrm{ml} \mathrm{L}^{-1}\right.$ air $)$ yaitu 35,0 hari, yang tidak berbeda nyata dengan perlakuan $\mathrm{p}_{1}, \mathrm{p}_{2}, \mathrm{p}_{4}, \mathrm{p}_{5}, \mathrm{p}_{6}$, dan $\mathrm{p}_{7}$, namun berbeda nyata dengan perlakuan $\mathrm{p}_{0}$. Sedangkan umur tanaman berbunga terlama dihasilkan dari perlakuan $\mathrm{p}_{0}$ (kontrol) yaitu 48,0 hari, yang tidak berbeda nyata dengan perlakuan $\mathrm{p}_{5}$, namun berbeda nyata dengan perlakuan $\mathrm{p}_{1}$, $\mathrm{p}_{2}, \mathrm{p}_{3}, \mathrm{p}_{4}, \mathrm{p}_{6}$, dan $\mathrm{P}_{7}$ (Gambar 2). Rata-rata jumlah buah pertanaman tertinggi dihasilkan dari perlakuan $\mathrm{p}_{6}\left(120 \mathrm{ml} \mathrm{L}^{-1}\right.$ air $)$ yaitu 44,55 buah, yang tidak berbeda nyata dengan perlakuan $\mathrm{p}_{0}, \mathrm{p}_{1}, \mathrm{p}_{5}$, dan $\mathrm{p}_{7}$, namun berbeda nyata dengan perlakuan $\mathrm{p}_{2}, \mathrm{p}_{3}$, dan $\mathrm{p}_{4}$. 


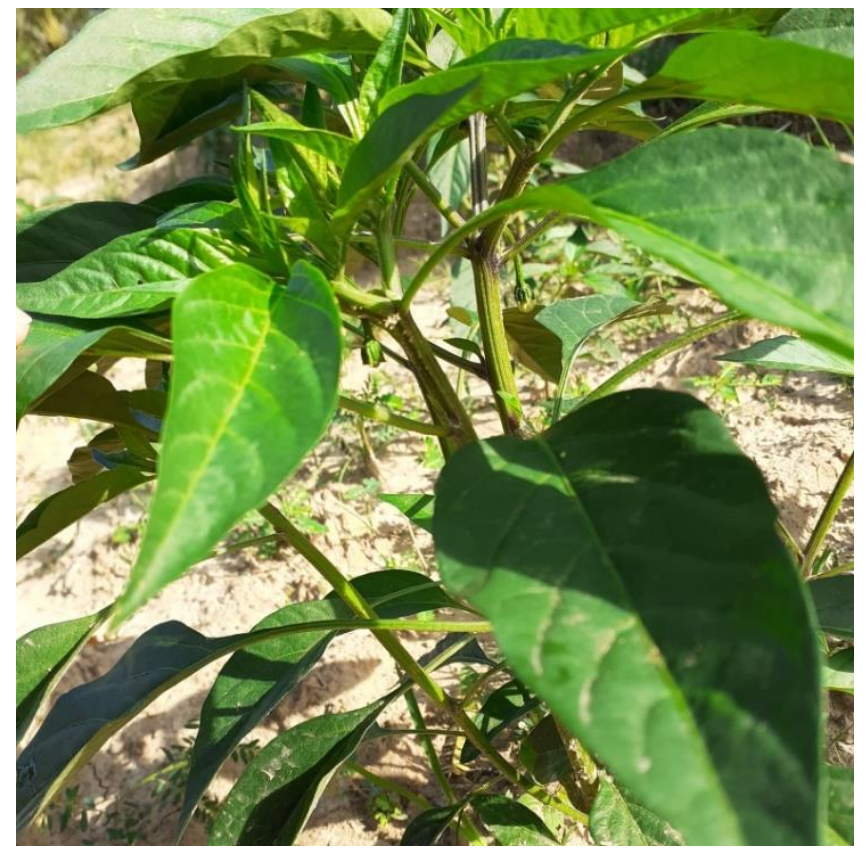

Gambar 1. Munculnya bunga pada tanaman cabai

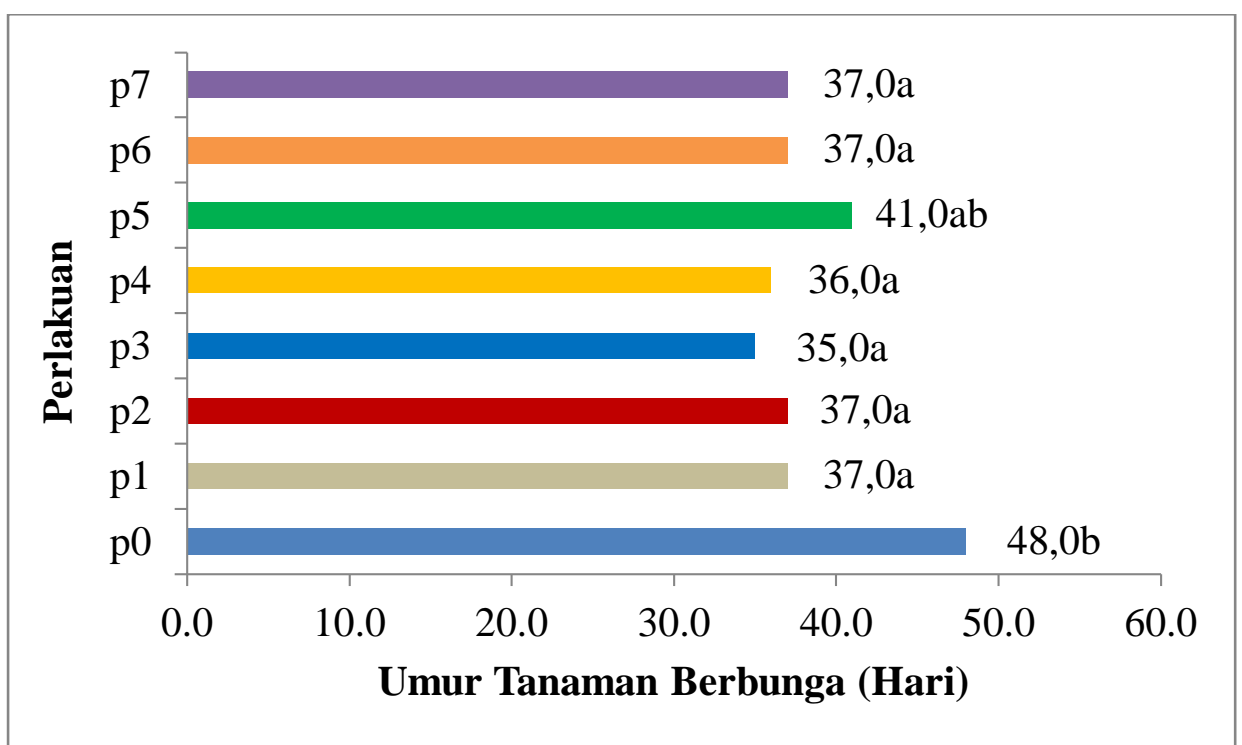

Keterangan: $\mathrm{p}_{0}=$ kontrol, $\mathrm{p}_{1}=20 \mathrm{ml} \mathrm{L}{ }^{-1}$ air, $\mathrm{p}_{2}=40 \mathrm{ml} \mathrm{L}^{-1}$ air, $\mathrm{p}_{3}=60 \mathrm{ml} \mathrm{L}^{-1}$ air, $\mathrm{p}_{4}=80 \mathrm{ml} \mathrm{L}^{-1}$ air, $\mathrm{p}_{5}=100 \mathrm{ml} \mathrm{L}^{-1}$ air, $\mathrm{p}_{6}=120 \mathrm{ml} \mathrm{L}^{-1}$ air, $\mathrm{p}_{7}=140 \mathrm{ml} \mathrm{L}^{-1}$ air

Gambar 2. Umur tanaman berbunga

Sementara itu, rata-rata jumlah buah pertanaman terendah diperoleh pada perlakuan $\mathrm{p}_{3}\left(60 \mathrm{ml} \mathrm{L}^{-1}\right.$ air) yaitu 21,83 buah, yang tidak berbeda nyata dengan perlakuan $\mathrm{p}_{2}, \mathrm{p}_{4}$, dan $\mathrm{p}_{5}$, namun berbeda nyata dengan perlakuan $\mathrm{p}_{0}, \mathrm{p}_{1}$, $\mathrm{p}_{6}$, dan $\mathrm{p}_{7}$ (Gambar 3). Pemberian konsentasi POC FPUKT-1 mempengaruhi kecepatan munculnya bunga dan jumlah buah cabai. 


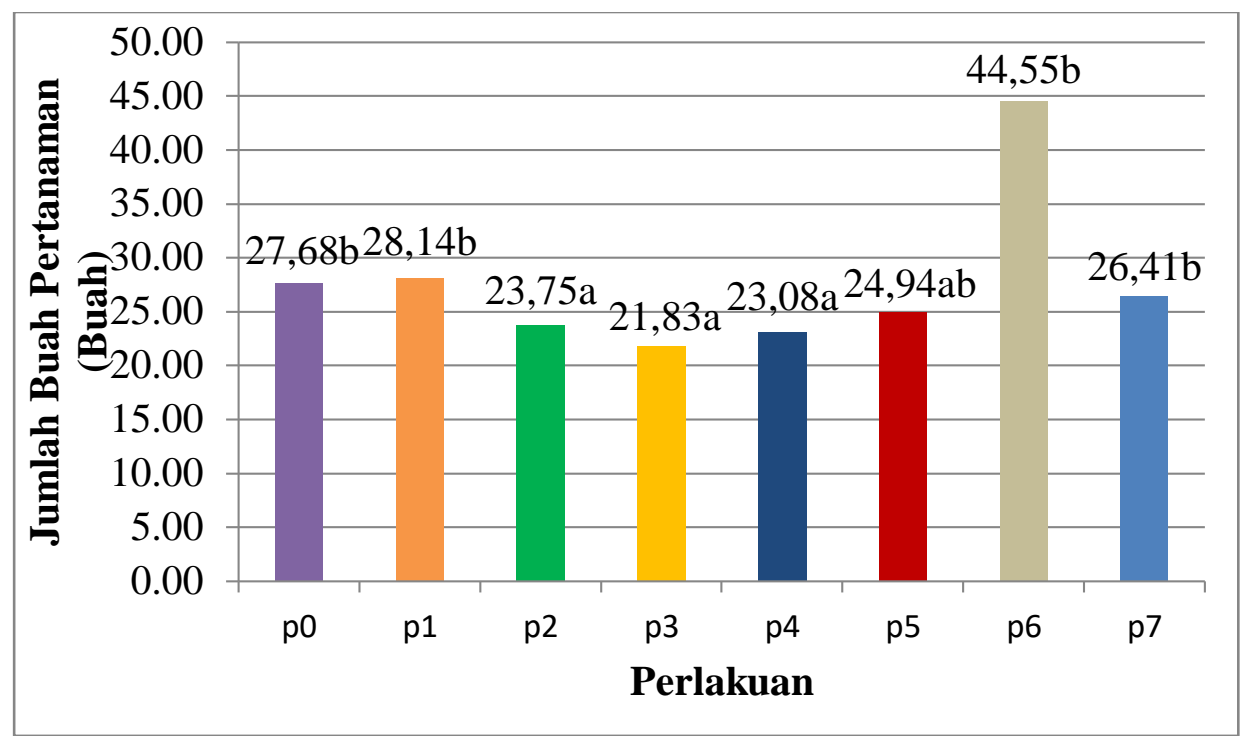

Keterangan: $\mathrm{p}_{0}=$ kontrol, $\mathrm{p}_{1}=20 \mathrm{ml} \mathrm{L} \mathrm{L}^{-1}$ air, $\mathrm{p}_{2}=40 \mathrm{ml} \mathrm{L}^{-1}$ air, $\mathrm{p}_{3}=60 \mathrm{ml} \mathrm{L}^{-1}$ air, $\mathrm{p}_{4}=80 \mathrm{ml} \mathrm{L}$ air, $\mathrm{p}_{5}=100 \mathrm{ml} \mathrm{L}^{-1}$ air, $\mathrm{p}_{6}=120 \mathrm{ml} \mathrm{L}^{-1}$ air, $\mathrm{p}_{7}=140 \mathrm{ml} \mathrm{L}^{-1}$ air

Gambar 3. Rata-rata jumlah buah pertanaman cabai

Hal ini karena komposisi yang ada pada pupuk organik cair FPUKT-1 telah tergabung, sehingga unsur hara yang terkandung didalamnya dapat digunakan oleh tanaman, salah satunya unsur P. Peran unsur P dalam pupuk organik cair FPUKT-1 yaitu untuk mempercepat pembungaan dan jumlah buah. Lingga dan Marsono (2008) menyampaikan bahwa unsur fospor (P) memiliki fungsi sebagai bahan mentah dalam pembentukan sejumlah protein tertentu, mempercepat pembungaan, pemasakan biji dan buah, serta membantu asimilasi dan pernafasan. Layanan Informasi Desa (2019) menambahkan bahwa unsur fospor sangat berguna bagi tanaman karena berperan penting dalam pembelahan sel untuk daun, buah dan biji, pembentukan albumin, serta untuk pembentukan bunga. Pupuk organik cair limbah sayuran memberikan sumbangan unsur hara $\mathrm{P}$ untuk tanaman sehingga mempercepat pembungaan, pembentukan biji dan buah, membantu pembentukan karbohidrat, protein, lemak, dan berbagai persenyawaan lainnya. Untuk masa generatif tanaman memerlukan unsur hara terutama $\mathrm{P}$, unsur hara $\mathrm{P}$ tersedia pada limbah sayuran dengan berbagai konsentrasi dapat mempercepat pembungaan untuk cabai besar. Hal ini dapat diduga karena unsur hara $\mathrm{P}$ lebih cepat diserap oleh tanaman cabai besar sehingga proses fotosintesis dapat berjalan lebih optimal (Febrianti, Damhuri dan Sudrajat, 2016).

Pemberian POC FPUKT-1 berbagai konsentrasi memberikan pengaruh tidak nyata terhadap rata-rata hasil buah segar pertanaman (g) dan hasil buah segar perhektar $\left(\mathrm{t} \mathrm{ha}^{-1}\right)$. Rata-rata buah segar pertanaman tertinggi diperoleh pada taraf $\mathrm{p}_{6}\left(120 \mathrm{ml} \mathrm{L}^{-1}\right.$ air $)$ yaitu sebesar 238,75 g, sedangkan yang terendah diperoleh pada taraf $\mathrm{p}_{3}\left(60 \mathrm{ml} \mathrm{L}^{-1}\right.$ air $)$ dengan rata-rata yaitu $122,17 \mathrm{~g}$. Rata-rata buah segar perhektar tertinggi diperoleh pada taraf $\mathrm{p}_{6}(120$ $\mathrm{ml} \mathrm{L}^{-1}$ air) yaitu sebesar 4,45 $\mathrm{t} \mathrm{ha}^{-1}$, sedangkan yang terendah diperoleh pada taraf $\mathrm{p}_{0}$ (kontrol) dengan rata-rata $2,18 \mathrm{tha}^{-1}$ (Tabel 1). 
Tabel 1. Rata-rata hasil buah segar pertanaman $(\mathrm{g})$ dan hasil buah segar perhektar $\left(\mathrm{t} \mathrm{ha}^{-1}\right)$

\begin{tabular}{ccc}
\hline Perlakuan POC FPUKT-1 & $\begin{array}{c}\text { Rata-rata hasil pertanaman } \\
(\mathrm{g})\end{array}$ & $\begin{array}{c}\text { Rata-rata hasil perhektar } \\
\left(\mathrm{t} \mathrm{ha}^{-1}\right)\end{array}$ \\
\hline kontrol $\left(\mathrm{p}_{0}\right)$ & 156,75 & 2,18 \\
$20 \mathrm{ml} \mathrm{L}^{-1}$ air $\left(\mathrm{p}_{1}\right)$ & 171,75 & 3,14 \\
$40 \mathrm{ml} \mathrm{L}^{-1}$ air $\left(\mathrm{p}_{2}\right)$ & 152,89 & 2,51 \\
$60 \mathrm{ml} \mathrm{L}^{-1}$ air $\left(\mathrm{p}_{3}\right)$ & 122,17 & 2,45 \\
$80 \mathrm{ml} \mathrm{L}^{-1}$ air $\left(\mathrm{p}_{4}\right)$ & 129,42 & 3,14 \\
$100 \mathrm{ml} \mathrm{L}^{-1}$ air $\left(\mathrm{p}_{5}\right)$ & 142,67 & 2,54 \\
$120 \mathrm{ml} \mathrm{L}^{-1}$ air $\left(\mathrm{p}_{6}\right)$ & 238,75 & 4,45 \\
$140 \mathrm{ml} \mathrm{L}^{-1}$ air $\left(\mathrm{p}_{7}\right)$ & 155,48 & 2,94 \\
\hline Uji F & tn & tn
\end{tabular}

Keterangan: $\operatorname{tn}=$ berpengaruh tidak nyata $(\alpha=5 \%)$

Berdasarkan data yang ada diperoleh rata-rata hasil buah segar pertanaman dan hasil buah segar perhektar menunjukkan angka yang tidak jauh berbeda dengan $\mathrm{p}_{0}$ (kontrol), bahwa sebenarnya pupuk organik cair FPUKT-1 juga memberikan hasil yang baik karena dalam komposisi pupuk terdapat kandungan $\mathrm{C}$ organik $0,85 \%$ (Tabel 2), yang mana kandungan $\mathrm{C}$ organik ini jika terjatuh ke tanah pada saat pemberian pupuk ke tanaman cabai dapat meningkatkan kesuburan tanah.

Menurut Echa (2011), C-Organik (bahan organik) merupakan sumber nutrisi bagi tanaman yang dapat memperbaiki struktur tanah, memperbaiki konsistensi tanah, memperbaiki karakteristik lingkungan, meningkatkan kualitas tanah, produktivitas tanah tinggi secara berkelanjutan, sebagai sumber energi, dapat mengurangi keracunan unsur hara mikro yaitu aluminium (Al) pada tanah masam, memperbaiki tata kehidupan jasad tanah, khususnya bakteri sehingga seluruh proses mikrobiologis dalam tanah berjalan lebih sempurna.

Pada pupuk organik cair FPUKT-1 ini juga terdapat kandungan $\mathrm{N}$ (Nitrogen) total $0,05 \%$ (Tabel 2), yang dimana $\mathrm{N}$ sangat dibutuhkan bagi tanaman untuk membantu pertumbuhan dan membuat tanaman lebih hijau. Menurut Rina (2015), unsur hara N termasuk unsur yang diperlukan dalam jumlah paling banyak sehingga disebut unsur hara makro primer. Unsur $\mathrm{N}$ diserap tanaman dalam bentuk ion amonium $\left(\mathrm{NH}_{4}^{+}\right)$atau ion nitrat $\left(\mathrm{NO}_{3}{ }^{-}\right)$. Umumnya unsur $\mathrm{N}$ menyusun $1-5 \%$ dari berat tubuh tanaman.

Tabel 2. Hasil analisis laboratorium pada POC FPUKT-1

\begin{tabular}{|c|c|c|c|c|c|c|c|}
\hline \multirow[t]{2}{*}{ No } & \multirow[t]{2}{*}{ Sampel } & \multirow[t]{2}{*}{$\mathrm{pH}$} & $\begin{array}{c}\mathrm{C} \\
\text { Organik }\end{array}$ & N Total & \multirow{2}{*}{$\begin{array}{l}\mathrm{C} / \mathrm{N} \\
\text { rasio }\end{array}$} & \multirow{2}{*}{\multicolumn{2}{|c|}{$\frac{\mathrm{Mg} / \mathrm{l}}{\%}$}} \\
\hline & & & \multicolumn{2}{|c|}{$\%$} & & & \\
\hline 1 & POC FPUKT-1 & 3,89 & 0,85 & 0,05 & 17 & 0,013 & 0,017 \\
\hline
\end{tabular}

Sumber: Laboratorium Tanah Faperta Unmul (2019)

Agar kandungan $\mathrm{C}$ organik dan $\mathrm{N}$ total pada pupuk dapat membantu memperbaiki unsur hara tanah maupun tanaman, faktor lingkungan seperti curah hujan, maupun hama dan penyakit perlu diperhatikan. Pada penelitian ini turunnya hasil buah pada tanaman cabai juga dikarenakan curah hujan, hama dan penyakit. Curah hujan yang rendah sangat berpengaruh terhadap hasil tanaman cabai karena dapat mengakibatkan adanya serangan lalat buah. Menurut Hasyim dkk., (2008) dalam Agus dkk., (2017), aktivitas lalat 
buah akan lebih intensif pada saat intensitas hujan rendah daripada intensitas hujan tinggi karena pada saat intensitas hujan rendah persentase keberhasilan pembentukan pupa menjadi imago dewasa dapat meningkat. Menurut data Dinas Pertanian dan Peternakan
Kabupaten Kutai Kartanegara (2020), curah hujan selama periode penelitian di bulan April 2020 pada saat tanaman terserang lalat buah tergolong rendah karena dibawah $100 \mathrm{~mm}$ (Tabel 3).

Tabel 3. Data curah hujan (mm)

\begin{tabular}{lccccc}
\hline \multirow{2}{*}{ Keterangan } & \multicolumn{5}{c}{ Bulan } \\
\cline { 2 - 6 } & Januari & Februari & Maret & April & Mei \\
\hline Jumlah & 277 & 101 & 131 & 98 & 279 \\
Maksimum & 90 & 34 & 52 & 39 & 87 \\
Hari hujan & 15 & 9 & 16 & 14 & 15 \\
\hline
\end{tabular}

Keterangan: Periode penelitian di bulan April pada saat tanaman terserang lalat buah dengan jumlah hujan $98 \mathrm{~mm}$ perbulan dan termasuk bulan kering (BK)

Sumber: Dinas Pertanian dan Peternakan Kabupaten Kutai Kartanegara (2020)

Hal ini sesuai dengan kriteria dalam klasifikasi iklim Oldeman berdasarkan perhitungan Bulan Kering (BK) dengan batasan memperhatikan peluang hujan, hujan efektif dan kebutuhan air tanaman, Bulan Kering (BK) merupakan bulan dengan rata- rata curah hujan kurang dari $100 \mathrm{~mm}$ (Harmoni, 2014).

Hama dan penyakit, hama yang menyerang yaitu lalat buah. Lalat buah mengakibatkan buah cabai menjadi berlubang dan berulat (Gambar 4).

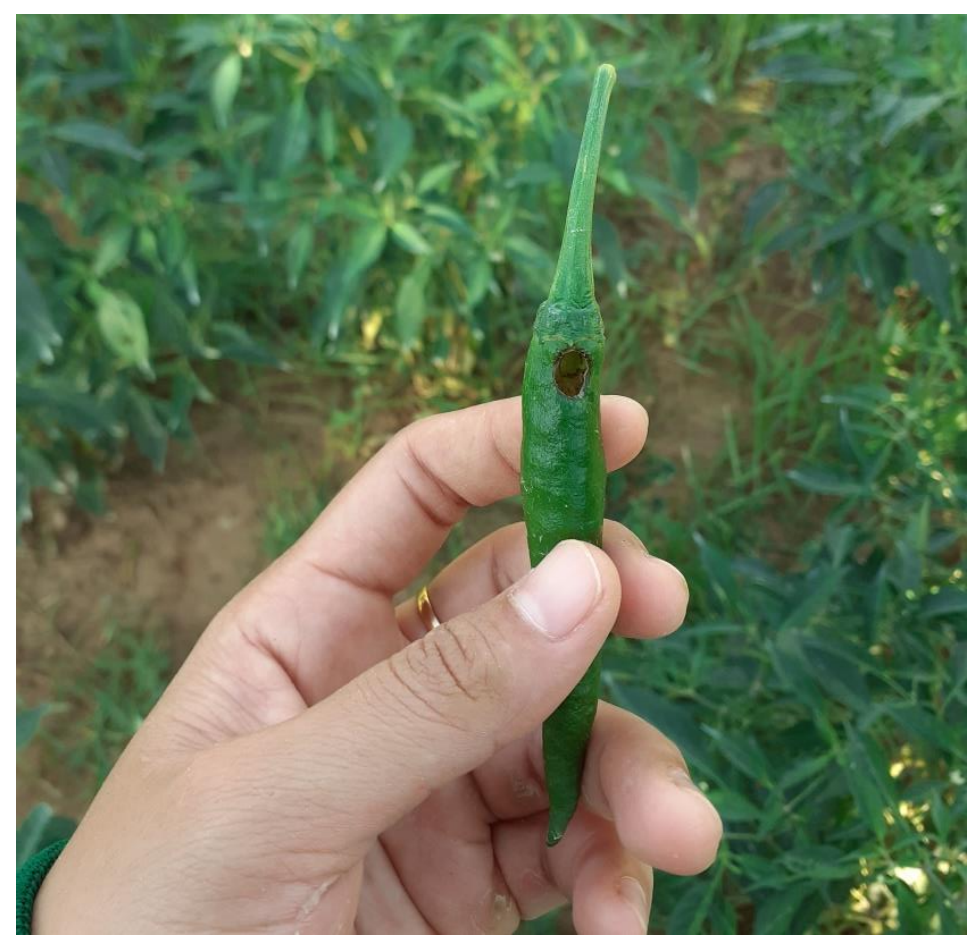

Gambar 4. Buah cabai yang berlubang akibat serangan lalat buah 
Lalat buah menyerang buah cabai yang bewarna hijau mengkilap sehingga cabai dipanen sebelum bewarna merah, karena saat buah akan bewarna merah buah cabai akan membusuk (Gambar 5).

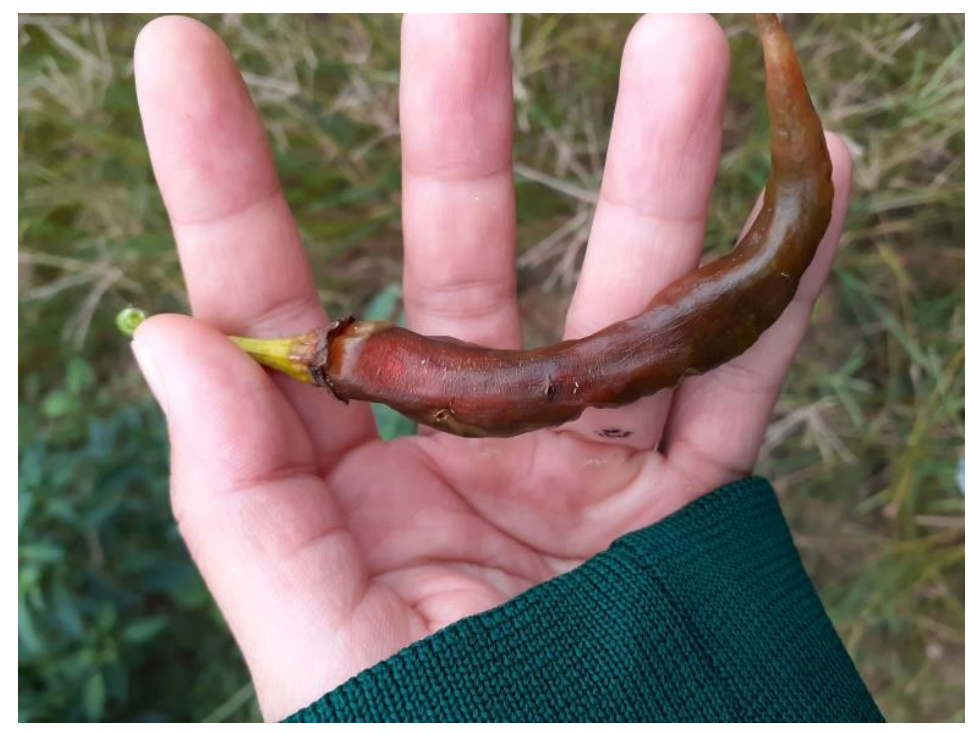

Gambar 5. Buah cabai yang membusuk akibat serangan lalat buah

Lalat buah betina dewasa menyerang cabai dengan cara memasukkan ovipositornya ke dalam buah cabai yang masih hijau untuk menyimpan telur-telurnya. Setelah 2-3 hari telur yang berjumlah 100 hingga 120 butir menetas menjadi berenga atau larva. Larva atau berenga ini yang merusak buah cabai sehingga menjadi busuk dan rontok. Larva yang menetas akan membuat terowongan sambil memakan daging buah cabai, keadaan ini berlangsung lebih kurang 2 minggu (Dinas Pertanian dan Pangan Kabupaten Gunung Kidul, 2019). Tingkat kematangan buah berpengaruh terhadap kematangan lalat buah. Buah yang hampir matang akan disukai lalat buah untuk meletakkan telur (Sutikno dan Siregar, 2015).

Penyakit yang menyerang yaitu busuk akibat bakteri Erwinia carotovora, bakteri ini menyerang buah yang sudah besar, akibatnya terjadi pembusukan diujung buah sehingga bewarna coklat kehitaman dan berbau (Gambar 6). Bakteri ini juga menyebabkan turunnya hasil panen karena buah membusuk sebelum waktu panen tiba. Menurut Dian (2012), pada umumnya infeksi ini terjadi melalui luka karena gigitan serangga seperti lalat buah, karena lalat buah mengandung bakteri didalam tubuh. Erwinia carotovora adalah bakteri yang dapat menyebabkan kematian sel melalui peruskan dinding sel tanaman dengan cara membuat sel secara osmosis mudah pecah. Gejala umum pada tanaman cabai yaitu busuk basah, dan bewarna coklat atau kehitaman. Adanya serangan bakteri sekunder, menyebabkan jaringan yang awalnya membusuk tidak berbau, menjadi berbau khas yang mencolok ke dalam hidung. 


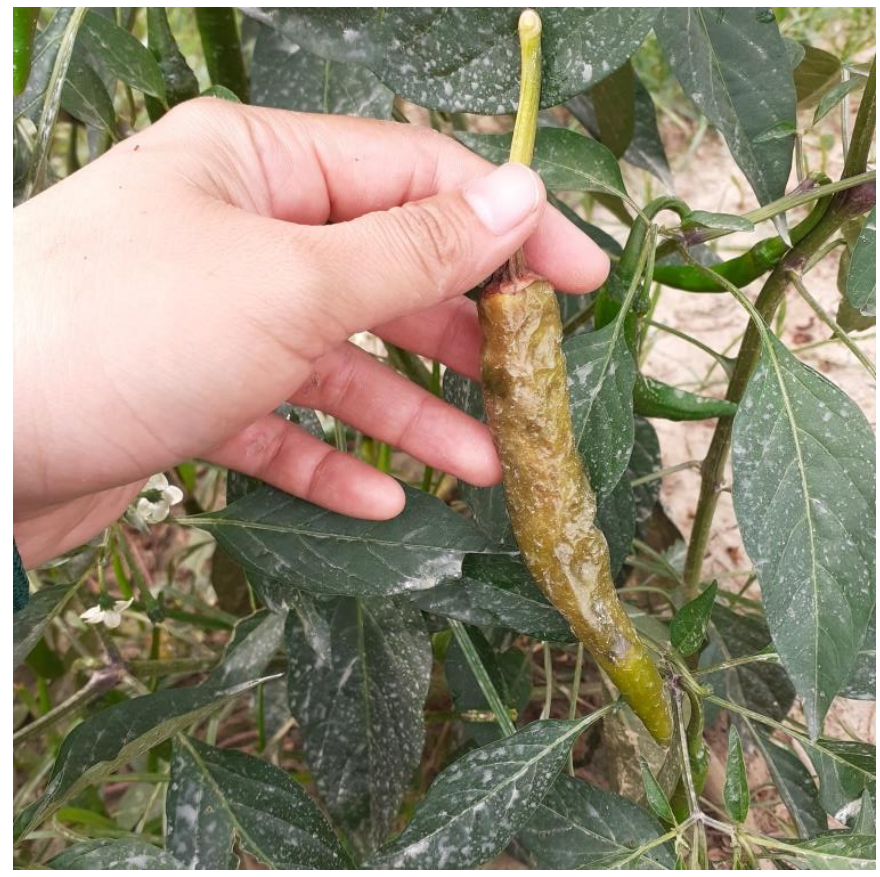

Gambar 6. Gejala serangan bakteri Erwinia carotovora pada buah cabai

\section{KESIMPULAN DAN SARAN}

\section{Kesimpulan}

Berdasarkan hasil penelitian dapat disimpulkan bahwa pemberian pupuk organik cair (POC) FPUKT-1 berpengaruh sangat nyata terhadap rata-rata umur tanaman berbunga dan berpengaruh nyata terhadap jumlah buah pertanaman. Umur tanaman berbunga tercepat dihasilkan dari perlakuan $\mathrm{p}_{3}$ (60 ml L $\mathrm{L}^{-1}$ air) dengan rata-rata yaitu 35,0 hari setelah tanam, sedangkan umur tanaman berbunga terlama dihasilkan dari perlakuan $\mathrm{p}_{0}$ (kontrol) dengan rata-rata yaitu 48,0 hari setelah tanam. Jumlah buah pertanaman tertinggi dihasilkan dari perlakuan $\mathrm{p}_{6}(120 \mathrm{ml}$ $\mathrm{L}^{-1}$ air) dengan rata-rata yaitu 44,55 buah, sedangkan jumlah buah pertanaman terendah diperoleh pada perlakuan $\mathrm{p}_{3}\left(60 \mathrm{ml} \mathrm{L}^{-1}\right.$ air $)$ dengan rata-rata yaitu 21,83 buah.

Pemberian pupuk organik cair FPUKT1 berpengaruh tidak nyata terhadap rata-rata hasil buah pertanaman dan hasil buah segar perhektar $\left(\mathrm{t} \mathrm{ha}^{-1}\right)$. Hasil buah segar pertanaman tertinggi dihasilkan dari perlakuan $\mathrm{p}_{6}(120 \mathrm{ml}$ $\mathrm{L}^{-1}$ air) dengan rata-rata yaitu $238,75 \mathrm{~g}$, sedangkan rata-rata terendah dihasilkan dari perlakuan $\mathrm{p}_{3}\left(60 \mathrm{ml} \mathrm{L}^{-1}\right.$ air $)$ yaitu $122,17 \mathrm{~g}$. Hasil buah segar perhektar tertinggi dihasilkan dari perlakuan $\mathrm{p}_{6}\left(120 \mathrm{ml} \mathrm{L}^{-1}\right.$ air $)$ dengan ratarata yaitu $4,45 \mathrm{t} \mathrm{ha}^{-1}$, sedangkan rata-rata terendah diperoleh pada perlakuan $\mathrm{p}_{0}$ (kontrol) yaitu $2,18 \mathrm{tha}^{-1}$.

\section{Saran}

Setelah dilakukan penelitian dapat dikemukakan saran yaitu dalam budidaya cabai besar menggunakan pupuk organik cair (POC) FPUKT-1 dengan konsentrasi $(120 \mathrm{ml}$ $\mathrm{L}^{-1}$ air ) untuk mendapat hasil terbaik. Selain itu, perlu dilakukan penelitian lebih lanjut terhadap POC FPUKT-1 dengan memperhatikan diantaranya faktor lingkungan, curah hujan, hama dan penyakit.

\section{DAFTAR PUSTAKA}

Agus, S., F. Fathoni, N.I.N. Atami, dan T. Tohidin. 2017. Fluktuasi populasi lalat buah (Bactrocera dorsalis Kompleks.) pada pertanaman pepaya di Desa Margaluyu, Kabupaten Garut. Jurnal Agrikultura. 28 (1): 32-38. 
Badan Pusat Statistika. 2020. Produksi tanaman sayuran dan buah-buahan semusim menurut jenis tanaman di Provinsi Kalimantan Timur (Kuintal) 2015-2018. Badan Pusat Statistika, Samarinda.

Dian, T.A. 2012. Identifikasi patogen (Erwinia carotovora). http://diantrias.blogspot.com/2012/12/e rwinia-caratovora.html. (Diakses pada tanggal 7 Juni 2020).

Dinas Pertanian dan Pangan Kabupaten Gunung Kidul. 2019. Waspada serangan lalat buah pada tanaman cabai. Dinas Pertanian dan Pangan Kabupaten Gunung Kidul.

Dinas Pertanian dan Peternakan Kabupaten Kutai Kartanegara. 2019. Laporan tahunan 2016/2017/2018. Dinas Pertanian dan Peternakan Kabupaten Kutai Kartanegara, Tenggarong.

Dinas Pertanian dan Peternakan Kabupaten Kutai Kartanegara. 2020. Data curah hujan stasiun kerjasama Badan Meteorologi dan Geofisika dengan Dinas Pertanian Propinsi Kalimantan Timur (dalam Mili Meter) tahun 2020. Dinas Pertanian dan Peternakan Kabupaten Kutai Kartanegara, Tenggarong.

Echa Y.T. 2011. Pengertian C organik. https://blog.ub.ac.id/yurike/2011/05/01/ c-organik/. (Diakses pada tanggal 3 Juli 2020).

Febrianti, Y, Damhuri dan H.W. Sudrajat. 2016. Pengaruh pemberian pupuk organik cair (POC) terhadap pertumbuhan dan produksi cabai merah
(Capsicum annum L.). Jurnal Ampibi. 1(3): 47-55.

Harmoni, K. 2014. Analisis persebaran iklim Klasifikasi Oldeman di Provinsi Daerah Istimewa Yogyakarta. https://scholar.google.com/scholar?clie $\mathrm{nt}=$ ms-android-samsung-gjrev1\&umm=1\&ie+UTF8 \&Ir\&q=related:zipAiHwkwRQykM:sc holar.google.com/. (Diakses pada tanggal 23 Juli 2020).

Laboratorium Tanah Fakultas Pertanian Universitas Mulawarman. 2019. Hasil analisis pupuk organik cair biji teratai. Faperta Unmul. Samarinda.

Layanan Informasi Desa. 2019. Peran unsur fospor (P) untuk tanaman. https://8villages.com/full/petani/article/ $\mathrm{id} / 5 \mathrm{c} 60 \mathrm{ddf} 8 \mathrm{ce} 212 \mathrm{bb} 21780 \mathrm{a} 933$.

(Diakses pada tanggal 7 Juni 2020).

Lingga, M., dan Marsono. 2008. Petunjuk penggunaan pupuk. Penebar Swadaya, Jakarta.

Rina. D. 2015. Manfaat N, P dan K bagi tanaman. $\quad$ http://kaltim.litbang. pertanian.go.id/ind/index.php?option $=\mathrm{c}$ om content $\&$ view $=$ article \&id=707\&Ite $\underline{\text { mid }=59}$. (Diakses pada tanggal 3 Juli 2020).

Susetya, H. 2015. Panduan lengkap membuat pupuk organik. Pustaka Baru Press. Yogyakarta.

Sutikno, A dan M.F.A. Siregar. 2015. Identifikasi lalat buah (Bactrocera spp.) pada tanaman buah di beberapa Kabupaten Provinsi Riau. JOM Faperta. 2 (2): 8 hal. 